\title{
Influence of humic acid applications on modulus of rupture, aggregate stability, electrical conductivity, carbon and nitrogen content of a crusting problem soil
}

\author{
İ. Gümüş and C. Şeker \\ Department of Soil Science and Plant Nutrition, Faculty of Agriculture, University of Selçuk, 42031 Konya, Turkey \\ Correspondence to: İ. Gümüş (ersoy@ selcuk.edu.tr)
}

Received: 23 July 2015 - Published in Solid Earth Discuss.: 7 September 2015

Revised: 20 October 2015 - Accepted: 21 October 2015 - Published: 11 November 2015

\begin{abstract}
Soil structure is often said to be the key to soil productivity since a fertile soil, with desirable soil structure and adequate moisture supply, constitutes a productive soil. Soil structure influences soil water movement and retention, erosion, crusting, nutrient recycling, root penetration and crop yield. The objective of this work is to study humic acid (HA) application on some physical and chemical properties in weakly structured soils. The approach involved establishing a plot experiment in laboratory conditions. Different rates of HA (control, 0.5, 1, 2 and $4 \%$ ) were applied to soil during three incubation periods (21, 42 and 62 days). At the end of the each incubation period, the changes in physicochemical properties were measured. Generally, HA addition increased electrical conductivity values during all incubation periods. HA applications decreased soil modulus of rupture. Application of HA at the rate of $4 \%$ significantly increased soil organic carbon contents. HA applications at the rate of $4 \%$ significantly increased both mean soil total nitrogen content and aggregate stability after three incubation periods $(p<0.05)$. Therefore, HA has the potential to improve the structure of soil in the short term.
\end{abstract}

\section{Introduction}

The widespread use of unsuitable and unsustainable production techniques in agricultural systems has resulted in extensive deterioration of soil quality and reductions in soil organic matter content and crop production (Verhulst et al., 2010; Martinez-Blanco et al., 2011). Soil quality is threatened by the increase in human population, by intensive man- agement of cultivable land and by urbanization and soil degradation. There is a general agreement that oil biochemical, microbiological and biological properties are more important than physical and chemical properties for the purpose of estimating alterations in soil quality and hence soil degradation (Keesstra et al., 2012; Paz-Ferreiro and Fu, 2013). Soil organic matter plays an essential role in nutrient $(\mathrm{N}, \mathrm{P}$, $\mathrm{S}, \mathrm{K})$ cycles, soil stability and the ecological and environmental aspects of sustainability of soil fertility (Garcia-Gil et al., 2004). Turkish soils generally have low organic matter levels and are commonly treated with mineral fertilizers that may improve yield in the short term but do not enhance the physical properties of the soil and result in soil degradation over the longer term. In many regions in Turkey, especially in Central Anatolia, the organic matter content of soils has fallen below 2 or $1 \%$ (Şeker and Karakaplan, 1999).

Organic materials are important soil additives to improve soil physical, chemical and biological properties. This is important to sustain the productivity of soils particularly in semi-arid regions (such as Turkey) where there is low input of organic materials. Usage of organic-based materials has gained importance within the last few years for sustainable agriculture and preventing soil degradation (Alagöz and Erdem, 2009).

Soil structure is often said to be the key to soil, with its ability to support plant and animal life, and moderate environmental quality with particular emphasis on soil carbon (C) sequestration and water quality. Understanding soil structural formation involves aspects of biology, chemistry, geology and physics within the context of the soil environment (Brevik et al., 2015). Using aggregate size, shape and distinct- 
ness as the basis for classes, types and grades, respectively, soil structure describes the manner in which soil particles are aggregated. Soil structure affects water and air movement through soil, greatly influencing a soil's ability to sustain life and to perform other vital soil functions. A well-developed structure and high aggregate stability are important for improving soil fertility, increasing agronomic productivity, enhancing porosity and decreasing erodibility. Aggregate stability is a reflection of soil structure and soil health in general because it depends on an integrated balance of chemical, physical and biological factors (Solera-Mataix, 2011; Brevik et al., 2015). Soil aggregate stability is widely regarded as one of the quality indicators in the soil system (Saygin et al., 2015). The decline in soil structure is increasingly seen as a form of soil degradation (Chan et al., 2003) and is often related to land use and soil-crop management practices. Structural and physical soil degradation is often associated with a decline in the organic matter content. Reports have indicated that loss of organic matter is generally associated with a decline in soil porosity and wet aggregate stability, as well as an increase in soil strength indices (Şeker and Karakaplan, 1999).

Certain components of soil organic matter such as polysaccharides, humic substances, root material and fungal hyphae have an important role in structural stabilization. Some synthetic conditioners which have shown promise for use in improving soil structure and physical properties at low application rates are polyacrylamides and polyvinyl alcohols (Bryan, 1992).

Humic acids and their salts, derived from coal and other natural sources, which have modes of action similar to synthetic conditioners, have been evaluated as potential soil conditioners. The advantage of humic substances is the refractory nature of their chemical structures that makes them more resistant to microbial attacks. Piccolo et al. (1997) reported that humic substances have a potential as soil conditioners in conversation practices aimed at increasing the structural stability of soils. Ersoy and Şeker (2004) reported that urban waste compost, cattle manure, chicken manure and leonardite improved soil aggregate stability values. Şeker (2003) reported that adding Portland cement and wheat straw to a soil having a crusting problem increased its aggregate stability; in turn seedling emergence of wheat was improved by decreased modulus of rupture and penetration resistance. Imbufe et al. (2005) suggested that potassium humate is potentially effective as a soil conditioner in improving aggregate stability of acidic and sodic soils against adverse effects of cyclic seasonal wetting and drying conditions. Bal et al. (2011) determined crusting problems of the KonyaSaricalar research station soils and offered some recommendations for a solution. As a result, an increase in the organic matter content and a reduction in agricultural practices to the minimum tillage were required in order to prevent crusting problems in the research soils.
The aim of this study was to determine the effects of humic acid applications on crust resistance, aggregate stability, electrical conductivity (EC), nitrogen and organic carbon of weakly structured soils.

\section{Materials and methods}

\subsection{Material}

Humic acid (trade name DELTA K-Humate) was supplied from a company. The soil sample used in this study has problems such as insufficient seedling emergency, low aggregate stability and crusting problems (Bal et al., 2011) Composited soil samples were taken from a problematic plot in the Agricultural Faculty of Selçuk University experiment station $(0-20 \mathrm{~cm}$ soil depth) near the Konya Sarıcalar village located in Central Anatolia, Turkey $\left(38^{\circ} 06^{\prime} \mathrm{N}, 32^{\circ} 36^{\prime} \mathrm{E} ; 1010 \mathrm{~m}\right)$. The climate is semi-arid, with an annual precipitation of $379.38 \mathrm{~mm}$, an annual mean temperature of $11.5^{\circ} \mathrm{C}$ and an annual mean evaporation of $1226.4 \mathrm{~mm}$.

\subsection{Methods}

The study was carried out in a randomized-plot design with three replications and conducted under laboratory conditions as a pot experiment. Surface soil samples $(0-20 \mathrm{~cm})$ were air-dried, ground through a $2 \mathrm{~mm}$ sieve and mixed homogeneously. Firstly, soil samples $(2000 \mathrm{~g})$ were placed in each pot (dimensions of pot; $13.5 \mathrm{~cm} \times 17 \mathrm{~cm}$ ). Five levels of HA (0\% (control), 0.5, 1, 2 and 4\%) were incubated. During the incubation period, the soil moisture level in the pots was maintained at $50-75 \%$ of field capacity. After various incubation periods (21, 42 and 62 days), the soil samples in the pots were mixed to ensure homogeneity in physical, chemical and biological properties. The soils were then subsampled (250 g) for analyses; 21-, 42- and 62-day incubation periods after the incubation of soil samples were analyzed with three replications.

Particle-size distribution of the soil was determined by the hydrometer method (Day, 1965). Soil water retention at field capacity $(-0.33 \mathrm{kPa})$ suction was determined by using a ceramic plate (Peters, 1965). Soil EC values were determined using a glass-calomel electrode in a $1: 2.5$ mixture $(v / v)$ of soil and water (Jackson, 1967). Soil organic carbon was determined on sample ground to pass through a $0.5 \mathrm{~mm}$ sieve by the using the TruSpec CN Carbon/Nitrogen Determinator (LECO Corporation 2006). The methodology used for measuring modulus of rupture (MR) as an index of crusting was that proposed by Reeve (1965). Aggregate stability was determined by immersing the sieves, containing the aggregate samples (between 1 and $2 \mathrm{~mm}$ size), in distilled water up and down oscillating on screens through $55 \mathrm{~mm}$ at 30 strokes $\mathrm{min}^{-1}$ for $5 \mathrm{~min}$ (Kemper, 1965). The data collected from the experiment were analyzed using analysisof-variance tests based on randomized-plot design (using F- 
Table 1. Properties of the soil used in the experiment

\begin{tabular}{llll}
\hline Soil properties & Values & Soil properties & Values \\
\hline Sand $(2-0.05 \mathrm{~mm})(\%)$ & 7.36 & Field capacity $(\%)$ & 31.14 \\
Silt $(0.05-0.002 \mathrm{~mm})(\%)$ & 37.72 & Wilting point $(\%)$ & 15.39 \\
Clay $(<0.002 \mathrm{~mm})(\%)$ & 54.92 & Aggregate stability (\%) & 14.37 \\
Textural class & Clay & Bulk density $\left(\mathrm{g} \mathrm{cm}^{-3}\right)$ & 1.34 \\
$\mathrm{pH}\left(\mathrm{H}_{2} \mathrm{O}, 1: 2.5\right)$ & 7.80 & & \\
$\mathrm{EC}\left(\mathrm{H}_{2} \mathrm{O}, 1: 2.5\right) \mathrm{d} \mathrm{S} \mathrm{m}^{-1}$ & 0.556 & & \\
Organic matter $(\%)$ & 2.95 & & \\
Carbonates $(\%)$ & 11.17 & & \\
CEC $\left(\mathrm{cmol} \mathrm{kg}^{-1}\right)$ & 33.6 & & \\
\hline CEC: cation exchange capacity. & & &
\end{tabular}

Table 2. Properties of the humic acid.

\begin{tabular}{ll}
\hline Properties & $\mathrm{HA}$ \\
\hline $\mathrm{pH}\left(\mathrm{H}_{2} \mathrm{O}, 1: 2.5\right)$ & $11-13$ \\
Organic matter $(\%)$ & 30 \\
Humic and fulvic acid $(\%)$ & 80 \\
$\mathrm{~K}_{2} \mathrm{O}(\%)$ & 10 \\
\hline
\end{tabular}

LSD at $P<0.05)$ according to the procedures outlined by Snedecor and Cochran (1980). All statistical results were calculated using the one-way analysis-of-variance procedure on MINITAB statistical software package (Minitab, 1995).

\section{Result and discussion}

Some physical and chemical properties of the soil and humic acid are given in Tables 1 and 2. The soil was characterized by having a clay texture, an alkaline soil $\mathrm{pH}$ (7.80) and organic matter and $\mathrm{CaCO}_{3}$ contents of 2.95 and $11.17 \%$, respectively.

\subsection{Effects of different rates of humic acid (HA) applications on soil modulus of rupture}

The effects of HA on soil modulus of rupture are given in Fig. 1. Modulus rupture of the soil treated with different doses of HA application was measured after 21-, 42- and 62-day incubation periods. The effects of HA application on modulus of rupture were significant $(P<0.05)$. Generally, soil modulus of rupture decreased with the increasing amendment rates of HA. These results may be explained by buildup of soil aggregate systems during incubation periods. The modulus of rupture was reduced because of the increase in HA treatments, which allowed less cohesion among the soil particles. Soil degradation caused by which may have led to a reduction in soil organic matter decomposition, soil erosion and nutrient leaching. The decreased soil erosion risk, nutrient leaching an organic matter decomposition rate helped in improving soil quality (Zhang et al., 2015). Similar positive effects were recorded with various forms of organic

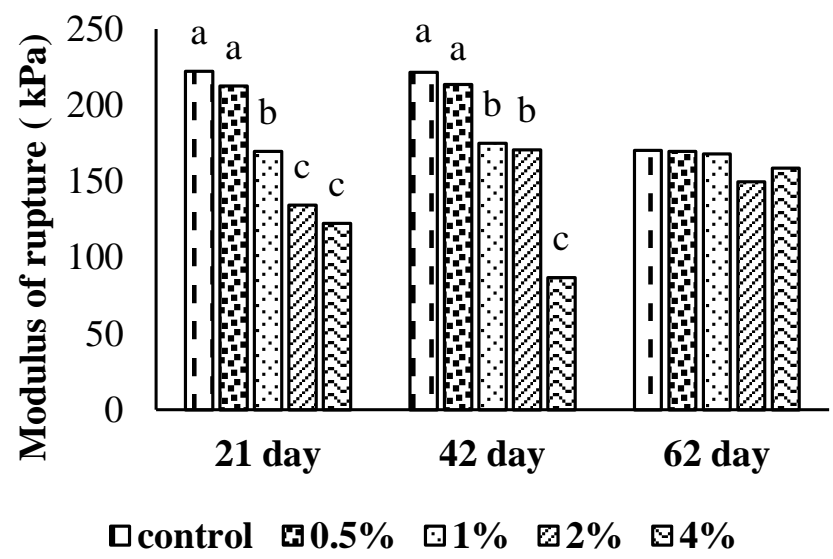

Figure 1. Effects of different rates of HA applications on soil modulus of rupture.

matter addition (Özdemir, 2002; Şeker, 2003). The possible mechanisms by which coal-derived humic acids improve soil physical properties are the formation of organomineral complexes by functional groups of the humic acids (Glaser et al., 2002).

\subsection{Effects of different rates of humic acid (HA) applications on aggregate stability}

The effects of HA on soil aggregate stability values are given in Fig. 2. Aggregate stability values of the soil treated with different doses of HA application were measured after 21-, 42- and 62-day incubation periods. The effects of HA application on soil aggregate stability values were significant $(P<0.05)$. Generally, aggregate stability increased with HA applications. These results may be explained by the fact that biological and physicochemical properties (especially, metal ions, humic or fulvic acids and carbohydrates content) can play a role in initial aggregate formation. Stability of microaggregates is strongly correlated with the humic matter content (humic or humic + fulvic acid) (Piccolo and Mbagwu, 1990). Kütük et al. (2000) reported that the highest number of water-resistant aggregates was obtained in the highest dose of humic acid application. Aggregate stability decreased in the 42- and 62-day incubation periods in all humic acid rates compared to 21-day incubation period. It is well known that soil organic matter, especially humic materials, is cementing agents in soil particles; however, certain organic components can paradoxically play a role as a dispersion element in claywater systems (Tarchitzky et al., 1993). Reduced input rate of organic matter and translocation of surface soils with water erosion are also reasons for low organic matter content of cultivated soils (Ozgöz et al., 2013). Lower organic carbon content in farmland caused a significant difference in aggregate stability values (Ozgöz et al., 2013). Shanmuganathan and Oades (1983) reported that addition of anions to soils causes dispersion in clay fraction associated with decreas- 


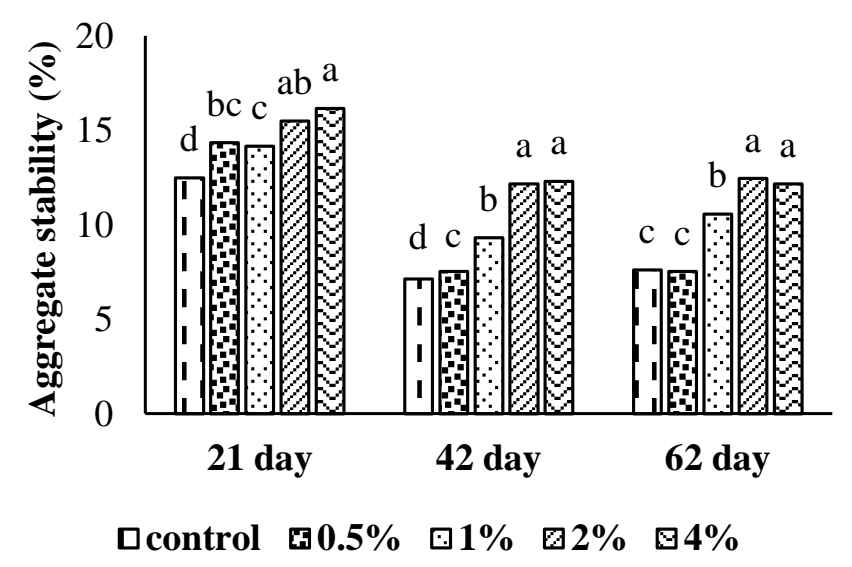

Figure 2. Effects of different rates of HA applications on aggregate stability.

ing isoelectric point, and it is known that especially fulvic acids are the most efficient anions. In addition, aggregate stability of the soil samples decreased after incubation periods due, most probably, to mechanical mixing practices (Şeker, 2003). Aggregate stability should be used judiciously and in concert with other indicators for an overall assessment of the soil physical quality condition (Moncada et al., 2013).

\subsection{Effects of different rates of humic acid (HA) applications on soil EC}

The effects of HA on EC values of the soil are given in Fig. 3. As illustrated in Fig. 3, the EC values significantly increased with respect to elevated HA application. According to the investigation at 21 days, the applications significantly increased the EC, except for $0.5 \%$. Investigation performed at 42 and 62 days revealed that soil EC linearly increased in response to increments in HA doses. The increasing EC values in experiment for different doses in HA application may be explained by rich nutrient composition of organic fragments and remains from the materials during incubation periods (Y1lmaz, 2010). Imbufe et al. (2004) reported that potassium humate application increased in soil $\mathrm{pH}$ and electrical conductivity. The present findings including the previous studies indicate that the increment in HA dose is accompanied by the elevation in soil EC level. For this reason, excessive use of HA should be avoided when HA is considered for use as a solvent substance for calcareous soils in agriculture.

\subsection{Effects of different rates of humic acid (HA) applications on soil organic carbon (SOC)}

The effects of HA on SOC values of the soil are given in Fig. 4. As illustrated in Fig. 4, the SOC values significantly increased with respect to elevated HA application. According to investigation at 21 days, the applications significantly increased the SOC, except for $0.5 \%$. Investigation performed at 42 and 62 days revealed that soil SOC linearly increased

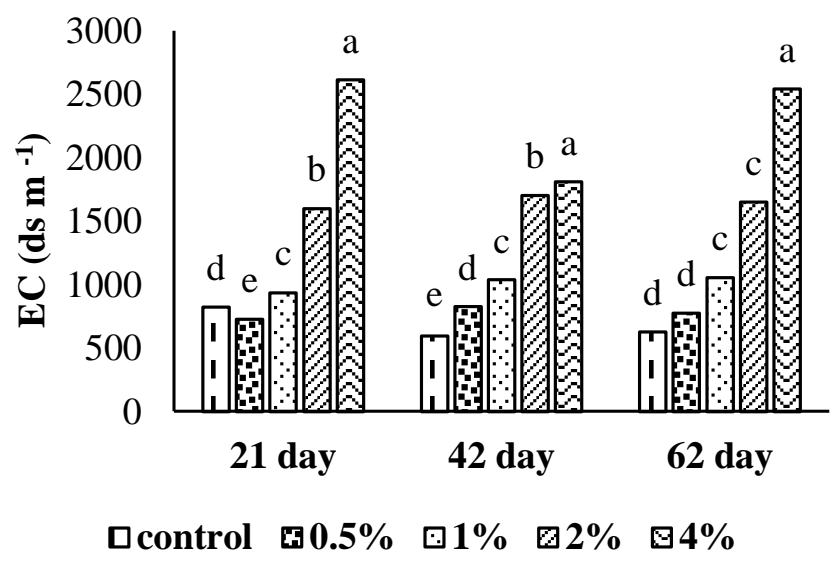

Figure 3. Effects of different rates of HA applications on soil EC.

in response to increment in HA dose and the strongest effect obtained with the doses 2 and $4 \%$, where differences in SOC values depending on incubation periods and rates of HA were noticed. SOC content of soil increased with increasing amendment rates of HA. Generally, SOC content values in experiments increase with the increase of amendment rates of organic materials. Total organic matter has long been recognized as an important determinant of soil performance. It depends on how much organic matter is added to the soil, how quickly it decomposes, and how much can be held by the soil. The amount, type and location of organic matter may be some of the best integrating indicators of many physical, chemical and biological processes (Lewandowski and Zumwinkle, 1999). SOC has been reported as dynamic soil quality indicators (Shukla et al., 2006; Zhao et al., 2015). Therefore, to assess the effect of changes in SOC content on soil structure condition, the aggregate stability can be considered as a good indicator (Moncada et al., 2013). SOC content, nitrogen and phosphorus are some of the most important chemical soil quality indicators for soil recovery and can drive changes in the biological, chemical and physical soil attributes (Vaconcellos et al., 2013). Similar positive effects were recorded with various forms of organic matter and arbuscular mycorrhizal fungi addition (Ferreras et al., 2006; Kavdır and Killi, 2008; Yılmaz, 2011; Vaconcellos et al., 2013).

\subsection{Effects of different rates of humic acid (HA) applications on total nitrogen $(\mathrm{N})$}

The effects of HA on total nitrogen values of the soil are given in Fig. 5. As illustrated in Fig. 5, the total nitrogen values significantly increased with respect to elevated HA application. According to investigation at 21, 42 and 62 days, the applications (2 and $4 \%$ ) significantly increased and has the strongest effects on the total nitrogen, except for $0.5,1$ and $2 \%$. However, amendments rates of doses 2 and $4 \%$ are similar. Generally, total nitrogen content of soil increased 


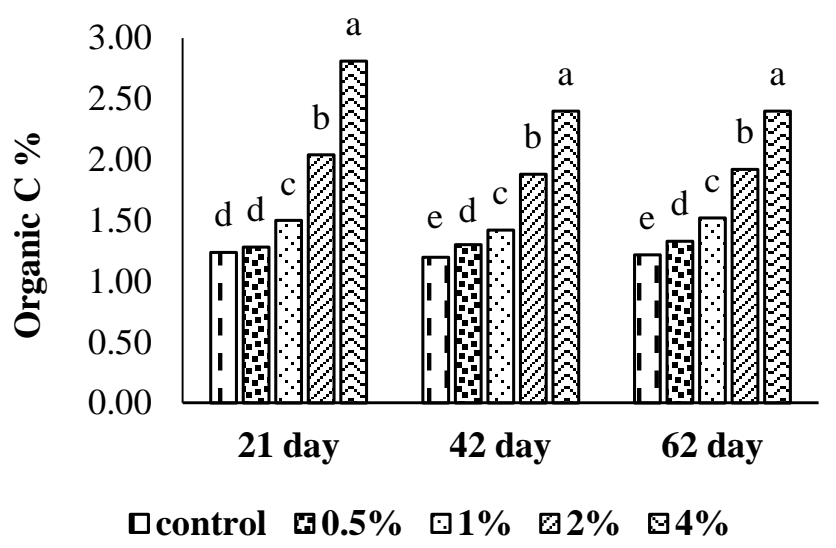

Figure 4. Effects of different rates of HA applications on soil organic carbon.

with increasing amendment rates of HA. Y1lmaz (2011) reported that biological and physicochemical properties of organic materials (especially $\mathrm{C} / \mathrm{N}$, decomposition and mineralization level) can play roles in mineralization of nitrogen from organic materials during incubation periods.

\section{Conclusions}

In conclusion, the results of this laboratory study indicate that humic acid applications can improve the stability of structurally soils. Chemical and physical properties of soil such as soil organic carbon, total nitrogen, modulus of rupture and aggregate stability were improved by HA amendment. HA increased soil EC and aggregate stability during the incubation period. Soil modulus of rupture was the most dramatically affected by the HA application. The use of HA may contribute to enhancing the level of organic carbon and nitrogen in soil. According to the results, HA (K-Humate) has potential to be used as an effective conversation and management tool for sustainability of the soil environment.

Edited by: A. Cerdà

\section{References}

Alagöz, Z. and Erdem, Y.: Effects of different sources of organic matter on soil aggregate formation and stability: a laboratory study on a Lithic Rhodoxeralf from Turkey, Soil Till. Res., 103419-103424, 2009.

Bal, L., Şeker, C., and Gümüş Ersoy, İ.: Kaymak tabakasıoluşumuna fiziko-kimyasal faktörlerin etkileri, Selçuk Tarım ve Gıda Bilimleri Dergisi, 25, 96-103, 2011.

Brevik, E. C., Cerdà, A., Mataix-Solera, J., Pereg, L., Quinton, J. N., Six, J., and Van Oost, K.: The interdisciplinary natur of soil, Soil, 1, 117-129, 2015.

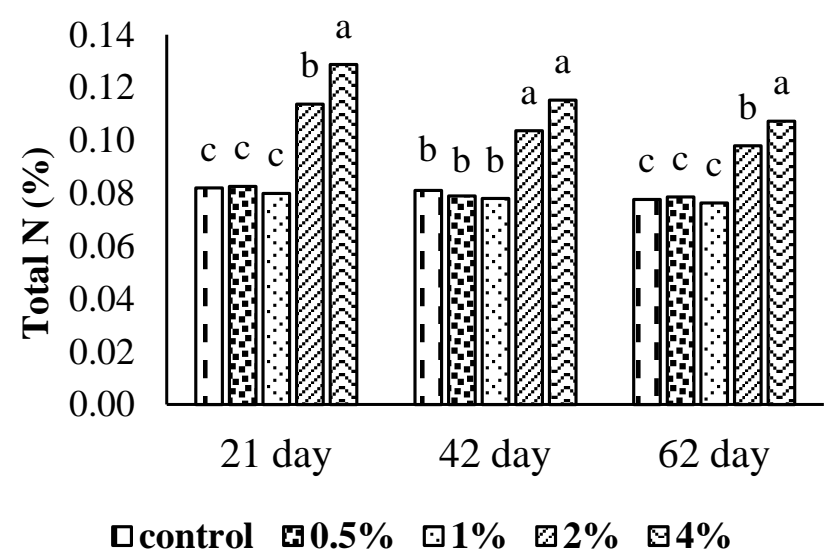

Figure 5. Effects of different rates of HA applications on total nitrogen.

Bryan, R.: The influence of some soil conditioners on soil properties: laboratory tests Kenyan soil samples, Soil Technol., 5, 225247, 1992.

Chan, K. Y., Heenan, D. P., and So, H. B.: Sequestration of carbon and changes in soil quality under conservation tillage on lighttextured soils in Australia: a review, Aust J. Exp. Agr., 43, 325334, 2003.

Day, P. R.: Particle fractionation and particle-size analysis, In: Methods of Soil Analysis, Part I, (Ed Black, C.A.), 545-566, American Society of Agronomy, Madison, WI, 1965.

Ferreras, L., Gomez, E., Toresani, S., Firpo, I., and Rotondo, R.: Effect of organic amendments on some physical, chemical and biological properties in a horticultural soil, Bioresource Technol., 97, 635-640, 2006.

Garcia-Gill, J. C., Plaza, C., Senesi, N., Brunetti, G., and Polo, A.: Effects of sewage sludge amendment on humic acids and microbiological properties of a semiarid Mediterranean soil, Biol. Fert. Soils, 39, 320-328, 2004.

Glaser, B., Lehmann, J., and Zech, W.: Ameliorating physical and chemical properties of highly weathered soils in the tropics with charcoal: a review, Biol. Fert. Soils, 35, 219-230, 2002.

Imbufe, A. U., Patti, A. F., Surapeneni, A., Jakson, R., and Webb, A. J.: Effects of brown coal derived materials on $\mathrm{pH}$ and electrical conductivity of an acidic vineyard soil, SuperSoil 2004: 3rd Australian New Zealand Soils Conference, 5-9 December 2004, University of Sydney, Australia, 2004.

Imbufe, A. U., Patti, A. F., Burrow, D., Surapaneni, A., Jackson, W. R., and Milner, A. D.: Effects of potassium humate on aggregate stability of two soils from Victoria, Australia, Geoderma, 125, 321-330, 2005.

Jackson, M. C.: Soil chemical analyses, Prentice Hall of India Private Limited, New Delhi, India, 1967.

Kavdır, Y. and Killi, D.: Influence of olive oil solid waste applications on soil $\mathrm{pH}$, electrical conductivity, soil nitrogen transformations, carbon content and aggregate stability, Bioresource Technol., 99, 2326-2332, 2008.

Keesstra, S. D., Geissen, V., Mosse, K., Piiranen, S., Scudiero, E., Leistra, M., and Van Schaik, L.: Soil as a filter for groundwater quality, Current Opinion in Environmental Sustainability, 281, 507-516, 2012. 
Kemper, W. D.: Aggregate stability, in: Methods of soil analysis, Part I, edited by: Black, C. A., American Society of Agronomy, Madison, WI, 511-519, 1965.

Kütük, C., Çaycı, G., Baran, A., and Başkan, O.: Effect of humic acid on some soil properties. In: Proceedings of the International Symposium on Desertification, Konya, Turkey, 324-328, 2000.

LECO Corporation: Truspec carbon/nitrogen determinator, Leco Corporation 3000, Lakeview Avenue, St Jeseph, M1 490852396, USA, 2003.

Lewandowski, A. and Zumwinkle, M.: Assessing the soil system: a review of soil quality literature, Minnesota Department of Agriculture Energy and Sustainable Agriculture Program, 1999.

Martinez-Blanco, J., Munoz, P., Anton, A., and Rieradevall, J.: Assesment of tomato Mediterranean production in open-filled and standard multi-tunnel greenhouse, with compost or mineral fertilizers, from an agricultural and environmental standpoint, J. Clean. Prod., 19, 985-997, 2011.

Minitab Inc.: Minitab reference manual (Release7.1), Minitab Inc., State Coll. PA, 16801, USA, 1995.

Moncada, M. P., Gabriels, D., Cornelis, W., and Lobo, D.: Comparing aggregate stability tests for soil physical quality indicators, Land Degrad. Dev., doi:10.1002/Idr.2225, 2013.

Özdemir, N.: Toprak ve su koruma, OMÜ Zir. Fak. Ders Kitabı, No: 22 Samsun, 2002.

Ozgöz, E., Günal, H., Acır, N., Gökmen, F., Birol, M., and Budak, M.: Soil quality and spatil variability assessment of land use effects in a Typic Haplustoll, Land Degrad. Dev., 24, 277-286, 2013.

Paz-Ferreiro, J. and Fu, S.: Biological indices for soil quality evaluation: perspectives and limitations, Land Degrad. Dev., doi:10.1002/Idr.2262, 2013.

Peters, D. B.: Water availability, in: Methods of Soil Analysis, Part I, edited by: Black, C. A., 279-285, American Society of Agronomy, Madison, W1, 1965.

Piccolo, A. and Mbagwu, J. S. C.:Effects of different organic waste amendments on soil microaggregates stability and molecularsizes of humic subtances, Plant Soil, 123, 27-37, 1990.

Piccolo, A., Pietramellara, G., and Mbagwu, J. S. C.: Use of humic substances as soil conditioners to increase aggregate stability, Geoderma, 75, 267-277, 1997.

Reeve, R. C.: Modulus of rupture, In: Method of soil analysis, Part 1, edited by: Black, C. A., 446-471, American Society of Agronomy, Madison, WI, 1965.

Saygın, D. S., Erpul, G., and Başaran, M.: Comparision of aggregate stability measurement methods for clay-rich soils in Asartepe catchment of Turkey, Land Degrad. Dev., doi:10.1002/Idr.2383, 2015 .
Shanmuganathan, R. T. and Oades, J. M.: Influence of anions on dispersion and physical properties of the A horizon of a red-brown earth, Geoderma, 29, 257-259, 1983.

Shukla, M. R., Lal, R., and Ebinger, M.: Determining soil quality indicators by factor analysis, Soil Till. Res., 87, 194-204, 2006.

Solera-Mataix, J., Cerdà, A., Jordàn, A., and Zavala, L. M.: Fire effects on soil aggregation: a review, Earth-Sci. Rev., 109, 44 66, 2011.

Snedecor, G. W. and Cochron, W. G.: Statistical methods (7th Edn.), Iowa State, University Press, Ames Iowa, 1980.

Şeker, C.: Effects of selected amendments on soil properties and emergence of wheat seedlings, Can. J. Soil Sci., 83, 615-621, 2003.

Şeker, C. and Karakaplan, S.: Konya Ovasında Toprak Özellikleri ile Kırılma Değerleri Arasındaki İlişkiler, Tr. J. of Agriculture and Forestry, 23, 183-190, 1999.

Tarchitzky, J., Chen, Y., and Banin, A.: Humic substances and pH effects on sodium and calcium montmorillonite flocculation of soil structure, Soil Sci. Soc. Am. J., 57, 367-372, 1993.

Vaconcellos, R. L. F., Bonfim, J. A., Baretta, D., and Cardoso, E. J. B. N.: Arbuscular mycorrhizal fungi and glomalin- releated soil protein as potential indicators of soil quality in a recuperation gadient of the Atlantic Forest in Brazil, Land Degrad. Dev., doi:10.1002/Idr.2228, 2013.

Verhulst, N., Govaerts, B., Verachtert, E., Castellanos-Navarrete, A., Mezzalama, M., Wall, P., Chocobar, A., Deckers, J., and Sayre, K.: Conversation Agriculture, Improving Soil Quality for Sustainable Production Systems, in: Advances in Soil Science: Food Security and Soil Quality, CRC Press, Boca Raton, FL, USA, 137-208, 2010.

Y1lmaz, E.: Changes of some soil properties by agricultural processing waste (soybean pulp) amendment, J. Food Agric. Environ., 8, 1057-1060, 2010.

Yilmaz, E.: Effects of different sources of organic matter on some soil fertility properties: A laboratory study on a Lithic Rhodoxeralf from Turkey, Communication in Soil Science and Plant Analysis, 42, 962-970, 2011.

Zhang, K., Zheng, H., Chen, F. L., Ouyang, Z. Y., Wang, Y., Wu, Y. F., Lan, J., Fu, M., and Xiang, X. W.: Changes in soil quality after converting Pinus to Eucalyptus plantations in southern China, Solid Earth, 6, 115-123, doi:10.5194/se-6-115-2015, 2015.

Zhao, X., Wu, P., Gao, X., and Persaud, N.: Soil quality indicators in relation to land use and topography in a small catchment on the loess plateau of China, Land Degrad. Dev., 26, 54-61, 2015. 